\title{
Discussion on New Measures for Universities to Promote and Deepen Innovation and Entrepreneurship Education Reform
}

\author{
Liu Xueping \\ Engineering Training Center \\ Shenyang Aerospace University \\ Shenyang, China
}

\author{
Wang Qingjun \\ School of Economy and Management \\ Shenyang Aerospace University \\ Shenyang, China
}

\begin{abstract}
In recent years, with the deepening of the "New Curriculum Standard" education reform, universities are constantly advancing and deepening innovation and entrepreneurship education which gradually becomes a trend of the education reform, and is also a highlight and focus of education in colleges and universities. However, the innovation and entrepreneurship education in our country is not optimistic at present, which is in its early stages without a large scale and good education effect even it has been started up for about one decade. Its demerits are vague positioning, ineffective result and implementation not in place. Therefore, based on current condition, it is urgent for universities to promote and deepen new measures for implement. This paper starts from the reality of innovation and entrepreneurship condition of various universities to deeply study on the development direction of education in universities so as to come up with comprehensive corrective measures and then analyze their effect as well as meaning, hoping to help the deepening and advancement of innovation and entrepreneurship education reform in universities.
\end{abstract}

Keywords-Universities; Innovation and entrepreneurship; New measures

\section{INTRODUCTION}

Innovation and entrepreneurship education is fundamentally an educational project, but also belongs to practical education, which does not only have creative but also innovative and practical features. In May this year, the State also published files in terms of innovation and entrepreneurship education, indicating that the government pays attention to education and shall greatly support it hoping to cultivate excellent talents. Nowadays, with the rapid development of social economics, both universities and students should actively seize the opportunity to try to cultivate the spirit of innovation and entrepreneurship, and then put into practice. So-called entrepreneurship is to demonstrate individual ideas in reality and entrepreneurs should be equipped with initiative, creative ability and spirit of adventure so as to tackle with various emergencies. Besides, universities are driving force to promote the innovation and entrepreneurship which can be deemed as the root and leading force to cultivate talents and therefore, they have to take on heavy tasks to carry out deep exploration and positively conduct reform in order to continually improve and promote innovation and entrepreneurship education system.

\section{CURRENT CONDITION OF INNOVATION AND ENTREPRENEURSHIP EDUCATION IN CHINA}

\section{A. Lack of innovation and entrepreneurship awareness from the perspective of students}

According to the data collected by Department of human resources and social security, there are 7,270,000 university graduates, with 280,000 increasing numbers comparing to $6,990,000$ in 2013 , hitting a new record. However, at present, only limited jobs are provided and it shall be impossible for every student to be recruited. Some graduate students choose to take part in the entrance exams for postgraduate schools or go abroad to further study in order to avoid the pressure. Only few students expect to start up their own business to realize their dreams and the fundamental reason is that they lack entrepreneurship awareness and spirit. Affected by the traditional education modes, modern university students lack entrepreneurship ideas and ability as well as techniques. Of course, there are unknown risks in the way and shall suffer from pressure from various sectors. In addition, there is a glittering array of uncertainties in terms of entrepreneurship opportunity difficulties and entrepreneurial success rate which leads to the condition that most of them do not take entrepreneurship into consideration.

\section{B. From the perspective of universities, they emphasize on employment and ignore entrepreneurship}

Innovative education in China began at the end of 20th century, which was officially launched in the early $21 \mathrm{st}$ century and 9 famous schools are taken as pilot schools. Judging from the current condition of innovation and entrepreneurship education, these schools mainly set career guidance curriculum which are carried out as selective courses and such coverage cannot help to achieve expected results. At present, it is marginalized and most of schools take is as part of alternative education system which is included in technical, economic or management courses and therefore its positioning is vague. Concerning the career guidance, career service centers are set up in most of universities yet there are not institutions to guide entrepreneurship. The graduation guidance focuses on employment while entrepreneurship is ignored. What's more, students do not only lack theoretical knowledge but also venture capital. According to the management system in colleges and universities, most of them adopt credit 
system which makes students only focus on learning and do not have spare time to pay attention to innovation and entrepreneurship, so most of the students choose to be employed rather than start up their own business.

\section{From the perspective of society, the social value of entrepreneurship is not obvious}

At present, the contemporary society is changing and universities are continually exploring in order to keep pace with times and the focus innovation and entrepreneurship education reform. China is a populous country, yet is not a great power. Even though China has diverse talents and abundant resources our national power as well as enterprise number does not accords with the current situation and therefore there are many chances to carry out entrepreneurship. Nowadays, students face great challenges, which shall last for a long time judging from the current situation. So, if students choose to reasonably start up their own business, they are able to solve this problem which can facilitate the flow of human resources in the employment market, and greatly relieve the employment pressure. Besides, university students can find out potential business chances by start up their own business and bring along with great wealth. Of course it is not to simply avoid the pressure on employment, but aims to demonstrate spirit and abilities and pursuit of hopes. However, the values brought by entrepreneurship has not been shown and some failure cases make students have the idea that entrepreneurship is beyond reach and is prohibitive

\section{NEW MEASURES FOR UNIVERSITIES TO PROMOTE AND DEEPEN INNOVATION AND ENTREPRENEURSHIP EDUCATION REFORM}

\section{A. Cultivate students' entrepreneurship awareness}

The fifth article of Higher Education Act stipulates that the task of higher education is to foster talents with innovative spirit and practical ability, develop science, technology and culture, promote socialist modernization. Students are main forces of contemporary social innovation and entrepreneurship, while schools are haven for students to learn and fountainhead of resources as well as the birthplace of talents. Therefore, schools have to take on the heavy responsibility to cultivate innovative and enterprising talents. However, in order to achieve this goal schools have to take students as main focus and always [ay attention to market trends so as to grasp market opportunities. The report of 18 th party congress also highlights that the ultimate goal of education is to serve the community, and therefore, innovation and entrepreneurship should try to facilitate the development of society, accumulate more wealth and better service the society. Of course, while carrying out innovation and entrepreneurship education the first step is to help them get rid of tradition ideas while be equipped with innovation and entrepreneurship awareness. The effect shall be better if it is done in freshmen year so as to provide students with help in terms of entrepreneurship based on their interests on willing while teachers carry out lectures. The most important point is to introduce entrepreneurship courses into credit management courses so as to encourage those boldly start up their own business while laying down their burdens.

\section{B. Change teaching model}

Traditional teaching model in China is dominated by teachers in the classroom, using infusion teaching. However, with the deepening reform of curriculum, the teaching models in various universities are changing and the role of students shine out. In order to better adapt to the innovation and entrepreneurship education, universities should encourage students take the initiative to interact and discuss and meanwhile teachers have to guide from diverse perspectives and converse thing mode. Besides, practical examples of entrepreneurship can be taken advantage of to gradually cultivate their abilities in facing and solving problems so as to stimulate their thinking ability. Besides, it is necessary to expand the coverage of small-scale class so as to focus on the training of creative and critical thinking ability which is beneficial to the production of inspiration. Finally, guide students to apply innovation awareness into practice to turn ideas into reality such as how to establish teams etc. Problems such as project implementation, team management, capital running should be guided by teachers so as to improve the success ratio.

\section{Change assessment mechanism}

While providing entrepreneurship opportunities and giving guidance, schools should also reasonably reform assessment contents and approaches. For these students, they have to focus on their strong analytical and problem solving skills and explore assessment system for nonstandard answers. Universities can start from their own perspective to find out the best appropriate and focus on the popularity of innovation and entrepreneurship education as well as the mining of social resources; besides, universities can introduce entrepreneurship into credit system and establish transformation of entrepreneurship and credit; for those who have willingness to start up their own business, universities should encourage them with help for example changing majors and learn other professional knowledge. If there should be conflict between entrepreneurship and schoolwork, universities should properly tackle with this problems and such as extending the time of term in order to create a sound environment for students to start up their own business.

\section{Carryout school-enterprise cooperation model}

School-enterprise cooperation model is not only the tendency for schools to participate in the innovation and entrepreneurship of universities but also an effective approach for universities to implement innovation and entrepreneurship education. In terms of innovation and entrepreneurship education universities pay attention to the theoretical guidance while there are few chances for practicing. Therefore, it is limited to implement this education in schools. In order to make up for this shortage and make students be equipped with not only knowledge but also skills, schools should full play internal enterprise capital, technique, team management to carry put schoolenterprise cooperation. Based on this, students with theoretical knowledge can be send to enterprises to participate in the decision making of enterprise project which is not only helpful to carry out project but also value 
opportunities for students who want to start up their own business.

\section{THE MEANING FOR UNIVERSITIES TO CONTINUALLY PROMOTE AND DEEPEN INNOVATION AND ENTREPRENEURSHIP EDUCATION}

\section{A. Beneficial for nations to implement the strategy of development driven by innovation}

A country's development is inseparable from the promotion of science and technology, and there won't be technological advance with innovation, therefore innovation is the power source for country to become strong and prosperous and is also the driving force to push the continuous development of society. With continuous development of science and technology, the wave of global technology revolution and industry change is again set off and China should seize the opportunity to properly deal with risks as well as challenges. Besides, facing the variation characteristics and tendency in the new era as well as historic tasks and goals of, it is necessary to deepen the mechanism reform and facilitate the strategy of development driven by innovation. In addition, an important meaning to promote and deepen the innovation and entrepreneurship is that it is conducive to the strategy of development driven by innovation.

\section{B. Beneficial to promote the upgrading of economy}

China is a populous country, and it has to do well in economic construction in order to develop. However, it has to properly deal with the relationship between healthy development and GDP growth to prevent the blind pursuit of GDP while ignoring the development quality as well as the stable and internal growth. Education is part of the social life, although it is restricted by economic development, it can facilitate the development of economic development and only when the education system is adapted to the economic development can this function be demonstrated. Innovation and entrepreneurship education is able to provide talents for modern construction and only when the economic development is being promoted can we innovate the technological achievements.

\section{Beneficial to promote comprehensive reform of advanced education}

Comprehensive reform of higher education covers a wide range such as education resources, teacher, education system, teaching model, and employment pattern which is difficult to implement. Higher education development as well as reform in China has experienced a decade years which is also developing and innovation and entrepreneurship education in universities choose the right time. Besides, to solve deep-rooted structural imbalance, improve the higher education quality shall gradually become the topic of education reform. In addition, to promote and deepen innovation and entrepreneurship education is able to fully demonstrate personal advantages, tap their potential to better implement modern system for university students and comprehensive reform of higher education.

\section{Beneficial to promote the employment and entrepreneurship of university students}

While facing high pressure to seek a job, students who have been exposed to innovation and entrepreneurship education are able to start from their advantages and tap potential so as to pursue entrepreneurship opportunity, relieve stress and improve success ratio. What's more, it is also for students to seek high quality work and the entrepreneurship education can bring along with the improvement of employment. According to big data, students who are exposed to innovation and entrepreneurship education can find it easily to be engaged in work and complete assignment. To condition, it can better promote both the employment and entrepreneurship of students.

\section{CONCLUSION}

Judging from the current situation, the innovation and entrepreneurship education in universities is not optimistic with diverse shortages and universities should positively adopt measures so as to further promote and deepen it to provide adequate talents for social economic development.

\section{REFERENCES}

[1] Zhao Yue. New Measures for Colleges to Promote and Deepen Innovation and Entrepreneurship Education $[\mathrm{J}]$. Economic Research Guide, 2015,20:170-172.

[2] Chen Yujuan. Research into College Students' Innovation and Entrepreneurship Education [D]. Hebei Normal University, 2013.

[3] Gong Min. Theories and Practices of College Students' Innovation and Entrepreneurship Education [D]. Huazhong University of Science and Technology, 2005.

[4] Tong Xiaoling. Research into Innovation and Entrepreneurship Education System in Researching Universities [D]. Wuhan University of Technology, 2012.

[5] Zhao Jinhua. Entrepreneurship Education in China's Polytechnical Colleges and Universities Based on Scientific and Technological Innovation [D]. Nanjing Normal University, 2014.

[6] Cao Yang. Research into Innovation and Entrepreneurship Education at Colleges and Universities under the Background of Transferring Economic Development Mode [D]. Northeast Normal University, 2014.

[7] Shi Guoliang. Innovation and Entrepreneurship Education for College Students in the Time [J]. Ideological Education Research, 2010,10:65-68. 